\title{
DEVELOPMENT OF STUDENT'S VALUES IN PEDAGOGICAL PROCESS
}

\section{Summary}

\section{Introduction}

In the sense of system-constructivistism, a competent individual orientates oneself in modern world, judges the values and is personally interested in his own profession and self-development. Aim of the Study

To find out the possibilities to facilitate the development of a student'value system.

\section{Materials and Methods}

In the article, the development of values is analysed as development of the individual's motivation sphere and understanding of the emotional experience. The pedagogical model is formed by including components from models of activity studies and reflective studies, and learning from experience into the model of pedagogical activity cycle.

\section{Results}

Pedagogical recommendations for organization of the pedagogical process which enables development of students'values.

\section{Conclusions}

Principles of formation of the student's and the educator's cooperation, which involve the student in a holistic meaningful activity and purposefully reflect it, are displayed.

Key words: pedagogical process at school higher education, development of values, experience, reflection.

\section{Introduction}

Professional higher education, as well as the aim of professional education of teachers is to educate a competent specialist for a specific field of activity, for performance of definite professional functions. But for a good professional nowadays it is not enough with competence as a set of grounded expertness, given knowledge, skills and attitudes. A graduate of the higher education must orientate in our world, be able to differentiate between "sense and senseless", become a part of a wider perspective (complexity), be able to evaluate it against the spectrum of values - aesthetic, moral, ecological and other, be personally interested in his own profession, development of his industry and his own self-development (Encyclopedia of higher education, 1992). Understanding of competencies of system-constructivistism connects independence, responsibility and creativity as traits of high level competencies with the idea of revelation of individual potential and development of personal experience which allows the student to reach personally significant goals and develop this competence life-long (Tillla, 2005). A competent person not only successfully reaches the goals entrusted for him, but at the same time sets and achieves his own goals and values, develops his professional identity (Medina Rivilla, 2003, 2005).

During the study process, it is expressed by incorporation of knowledge and skills to be mastered into the student's personal structures: how important are the student's own activities, 
how the studies harmonize with the student's personal sense, his values, whether the student is inwardly motivated to study, whether the student has personal attitude towards the content and form of the studies, whether the student critically evaluates his studies and his own self (Barnett, 2005; Rubene, 2004). Pedagogical approach is focused on the student; the student is the subject of the study process.

Subjective components of the competence, the "personal" features are revealed by the subject's values as the inner landmarks for the individual's behaviour and activities. Whatever the knowledge and skills are, the individual will act according to his own understanding and values when taking decision in a complicated situation of choice.

The university environment usually does not provide discussions on values; giving possibility to different value systems to coexist (Barnett, 2003). The student is an adult, autonomous personality, and in a democratic, tolerant situation, no intervention is allowed into the internal structure of student's personality; the programs of institutions of higher education disassociate from the idea of influencing the student's value system. There is a contradiction - on the one hand, the result of the higher education is defined stressing the development of the student's personality, inner motivation and values. On the other hand - the study programs and descriptions of study courses speak little of that, thus the university does not bind its responsibility to the development of the student's individuality and personality, referring it to children and adolescents, and not to students of institutions of higher education.

Value system of an adult continues to develop and improve during the whole life (Франкл, 1990; Eriksons, 1998; Vidnere, 1999), thus also during the studies without regard to whether it is guided purposefully or not. The question is whether and how the study process can develop the student's values in an institution of higher education for pedagogy so that the student can strengthen his own identity and could better orientate himself in the popularity of values typical of the period, at the same time acquiring the professional education of good quality.

\section{Aim of the Study}

To analyse the possibilities of development of students' value system within the pedagogical process of institutions of higher education and to offer a theoretical model for pedagogical activity.

\section{Materials and Methods}

Theoretical analysis and formation of the model.

\section{Development of adult's values}

Value is individual's relations with the object of value (which can be any material or nonmaterial object), which is characterised by the object's importance to the subject (Столович, 1999). In psychology, the value is discussed as a component of the subject personality's affective sphere, which similarly to inclinations, needs, emotions, feelings, interests, structure and organise the individual's behaviour and causes activity being the inner regulator of the human behaviour and activity. The value relates to high level motivation processes (motives creating meaning, autonomy of functionality), the individual chooses it as a mature personality with developed cognitive processes and conscientious will, they are intentional, freely chosen (inner motivation), directed towards future, related to search for meaning; they cover an endless diversity of the individual's motives observing the uniqueness of the definite person (Леонтъев А., 1975; Франкл, 1990; Karpova 1994, 1992; Eriksons, 1998; Plaude, 1999; Allport, 2002). The values are consistent inner landmarks for human activity, which integrate into the structure of the personality irrespectively of the situation and are reflected in aims, principles, conviction, attitudes, choice, 
personal characteristics, individual style (Rokeach, 1973; Schwarz, Bilsky, 1987; Allport, 2002; Karpova, 1994; Seligman, Katz, 1996; Vidnere, 1999).

Development of values takes place as development of motivation sphere; it is equivalent to development of personality (Allport, 2002). The value is lined with the individual during the process of internalisation of the value; objective need or society norm becomes the component of the structure of the individual's personality. The dominant of motivation moves from external to internal, social orientation is balanced by the individual one. An already internalised value can change its place in the hierarchy of values, making some values more important, and some lose their importance. Gradually the old stereotypes formed in the awareness when the person chooses values which are needed for the situation and proven in life, a change of conviction takes place rapidly or gradually, old commitments are put aside (Леонтъев А., 1975; Vidnere, 1999; Eriksons, 1998). During the integration process of values, the value proven by the experience becomes more saturated "symbolically intentional, recognised as reasonable within the context of the individual and society, the value chosen by a mature personality is implemented in life, tried out in circumstances of life and stays unchanged", it expresses the individual's positive activity in any circumstances (Vidnere, 1999). Table 1 collects theories dealing with development of the sphere of human motivation.

Table 1. Theories analysing the development of the sphere of human motivation.

\begin{tabular}{|l|l|}
\hline M. Rokeach, (1967) & Theory of human values \\
\hline A. L̇eontjevs (1975) & Theory of activity \\
\hline Krahtvalls (1968) & Taxonomy of affective aims of education \\
\hline Bitinas, (1984) & Theory of upbringing. \\
\hline Kohlberg, Piaget (1975) & Theory of moral development \\
\hline M. Vidnere (1997) & Understanding of emotional experience \\
\hline D. L̦eontjevs (1998) & Psychology or art \\
\hline
\end{tabular}

Analysing these theories, we find out that the internalisation of the subject's values (as well as the saturation of an internalised value) takes place, first, when the subject contacts with some value in his experience, using it in practice and experiencing it emotionally. Second, when the subject evaluates the emotional significance of the implemented values and their relations with his own subjective meaning, looking at its proportions to other values important for him and the society (Figure 1). When taking part in activities which may provide experience of value, and when analysing this own experience, an active involvement of the subject is necessary, "work with oneself” (Rogers, 1961; Karpova, 1994; Vidnere, 1997, 1999).

Figure 1. Stages of the process of value internalisation.

\begin{tabular}{|c|c|c|c|c|c|c|c|c|}
\hline $\begin{array}{c}\text { Knowledge } \\
\text { on the } \\
\text { value (1) }\end{array}$ & $\Rightarrow$ & $\begin{array}{l}\text { Direct } \\
\text { experience } \\
\text { of value in } \\
\text { action }(2)\end{array}$ & $\Rightarrow$ & $\begin{array}{l}\text { Evaluation of } \\
\text { the emotional } \\
\text { experience of } \\
\text { the value (3) }\end{array}$ & $\Rightarrow$ & $\begin{array}{l}\text { Analysis of } \\
\text { the } \\
\text { subjective } \\
\text { meaning of } \\
\text { the value } \\
(4)\end{array}$ & $\Rightarrow$ & $\begin{array}{l}\text { Implementation } \\
\text { of a new value } \\
\text { in socially and } \\
\text { personally } \\
\text { significant } \\
\text { activity (5) }\end{array}$ \\
\hline
\end{tabular}

These stages of value development reveal the student's activity, which stimulates the development of the student's values during the pedagogical process (relations 2-4-6, Figure 2). 
1. Knowledge on the value, social concept, conviction on what is good (beautiful, correct, true, useful, holy and the like), and how one should act. Individual's consciousness reflects the symbolic meaning of the value (Vidnere, 1997). Value - it is the reasonable, the sensible which is not there yet, but it should be there, and it is worth to strive for it (awareness of value). In this stage, the value exists in the human consciousness as a social norm, knowledge on what are the socially recognised norms, principles and virtues. The individual himself personally has not met the object of the value; his experience of value is mediated through some external authority (Rokeach, 1973; Битинас, 1984; Walklin, 2002).

2. Direct experience of the value in action, experience of value. The individual meets the object of the value, a direct experience of the value in the activity takes place thus causing emotional experience and the individual reacts to it, responds to it (Walklin, 2002, cf. Krahtwall). The individual subjectively feels the significance of the value. Emotions, which are felt in this process, are positive or negative not in relation to the result of the activity but to its adequacy to the motive. Emotional mood orders to value the hierarchy of motives; positive emotions witness that activity corresponds to the individual's motives which form the meaning and the highest of them - meaning of life (Леонтъев А., 1975). When the value changes from the given motive to a real tangible motivated force, becoming a real motive, it acquires a powerful potential of energy, the motive acquires new meaning (Vidnere, 1997).

3. The subject's intensive "work with himself" follows. In the beginning, the individual evaluates his own emotions acquired when meeting the respective value. The stronger are the emotions, the larger is the need for restructuring of one's values, the stronger is the subject's motivation to move to the process of value analysis, which is more difficult and complicated. The more positive are the emotions, the larger is the possibility that the respective activity and values used in it are related to the individual's meaning of life, the easier it is to accept this value as his own (Леонтъев А., 1975).

4. At the second stage of reflexion, analysis of the subjective meaning of the value experience takes place; the value is included in the present value hierarchy. The object is compared to the existing meaning of life. After the emotional experience, the issue of this object (activity) correlation with the individual's life actual facts should be solved, and solution to this issue is that mental activity referred to by Vidnere and others. Therefore, there is some exercise of meaning. One can ask oneself about the activity: Why am I doing this (did, intend to do?), what are the needs or values which are implemented in this activity, what will be (are) the consequences of this activity. One can ask about the object: What is the place it occupies in my life, what aspects of my life have are not indifferent towards it, how can it influence my life (Леонтъев Д., 1998). A mature person values the level on which the object (realised value) actualises the individual as oneself(Rogers, 1967; Vidnere, 1997). In this stage of evaluation all levels of personal meaning are involved, they cover the individual's relations with the society, thus considering also the social significance of the experienced value. As a result of analysis, the new value is included in the present value hierarchy. A wish appears to act in accordance with this value; a decision is taken on the further activity in compliance with it, understanding of the emotional experience (Vidnere, 1997).

5. Use of the new value in activity important for the society and the person. Result of the value internalisation (saturation) is change of motives or values, they have become as the new, better understood, more diverse position of a matured, saturated personality (Битинас, 1984; Karpova, 1994). The value is included in the student's value system for a sufficiently long time 
to develop a characteristic "way of life". Practical use of the value becomes a stable behaviour (Битинас, 1984); character of the person has been changed.

The person does not always like to change himself; resistance of the former motives is observable. As soon as one of the stages of value development is missing, the individual although aware of the new situation and recognising the significance of the new value does not accept it, rather he simulates, mechanically learns the new model of behaviour, ignoring his associative ties, denies the reality, replaces, drives out, regresses in illusions, projects, rationalises (blocks the real feelings) (Rogers, 1967; Griffin, Holford, Jarvis, 2003; Vidnere, 1999). In fact, it is crucial in the process of value formation - which is more powerful - the present value system or the new emotional experience. The time is also important, it is necessary for changes to take place and for the new, adequate concept to appear for what has happened and its true evaluation.

Thus, the educator has theoretical possibilities to facilitate the development of student's values in each stage: 1 ) by analysing the social concepts; 2) ensuring a direct, emotional experience of the value; 3 ) organising the evaluation of the emotional trends and analysis of the subjective meaning.

\section{Pedagogical process stimulating the development of student's values at the institution of higher education}

The only way for the studies to change the student's behaviour, further activities, attitudes, choice and personality are the studies, which are focussed on the student and are self-revealing and self-adequate because even most experienced and interested educator cannot communicate his own experience to others. This means to create circumstances for possibilities to reveal human uniqueness, self-regulation and self-initiative (Rogers, 1967; Knowles, 1950, 1998). Therefore the model for development of student's values is made by concretising model developed by Čehlova (Špona, Čehlova, 2004) for pedagogical activity cycle, which shows the pedagogical activity as joint action of the student and the educator for reaching objective and subjective goals, the process of their implementation and results (Figure 2).

Aim of the pedagogical activity is the development of student's values which should be coordinated with the individual values and motives of the student (model $1-2$ ). The psychological theories do not talk about motivation which stimulates the change of values; rather they talk only of situations which stimulate the individual to re-evaluate his values. An open possibility for development (or stagnation) of human identity is a crisis in psychological meaning as an internal or external conflict situation (Eriksons, 1998), contradictions in human viewpoints and conviction (Kohlberg, 1984; Crain, 1985), extreme situations hazardous for human life, when due to external circumstances the person has to change his life in order to keep the identity of his personality (Франкл, 1990, Vidnere, 1997) or the culmination of experience when due to religious or aesthetic emotions causing the highest levels of happiness, harmony and possibilities the person changes his life (Маслоу, 1970, 2003; Леонтъев Д., 1998) choosing another style of life, other aims, higher values, attitudes, conviction, forming character. Effective changes to the system of values will be as an ancillary product to the activity, which comes into being by reflecting one's experience to the process of activity. The initial motivation will be: express, understand, feel, tell, improve one's life, experience, solve a conflict, involve in an activity instead of changing one's opinions of values. Bitinas acknowledges that a student may be unaware of the upbringing process, he can see it as his own life activity (Битинас, 1984).

Actualisation of the concept of values or creation of new concepts takes place when the student acquires any new information which includes any evaluation, introduces any norms or 
principles. Educator's possibilities to actualise problems of specific values are given by choosing the content of studies. The chosen theme should be 1) important within the view of an individual, 2) giving opportunity to autonomous activities, 3) not trivial, 4) personal (Brockbank \& Megil, 2004). It is important to relate the studies with real problems of life and conflicts of values instead of avoiding them; dialogues of contrasts can be included in any subject of studies relating to any content of values. By involving the student's own experience in life and initiative into the study process, the studies become personally important, the content of the studies naturally relates the new knowledge to the previous knowledge and the student knows what and why he chooses (Roger, 1961, Knowles, 1998, Walklin, 2003). The theme can be chosen by the educator, the group, the leader of the group or a person (Kirhenbaum, 1992).

Within the stage of pedagogical activity (model 3-4), experience of the value takes place (direct, personally significant experience of the value in activity) as well as the evaluation of the emotional colouring and subjective meaning of this experience. From the point of view of didactic models, those teaching models are important which involve in well-considered proportions the reflection of the student's life and experience of activities within the study process. Theses are didactic models orientated to learning and interrelation (Eisner, 1980, 2001; Kron, 1999; Tillla, 2005) - models of experiental learning, action learning and reflective learning.

Notion of experience is very broad. The individual's experience can be primary or secondary (direct or mediated), actual or reproduced, natural or artificial, short-term or long-term, emotional or reflected. All these types have in common the fact that the person experiences (feels) the situation in personal whole, involving the cognitive, affective and voluntary structure, past, present and future. "Definite experience - total involvement into the direct experience here and now". Creation of experience is internal process, the experience is constructed; it is personal, it includes individual traits in the personality, as well as the social and cultural contexts (Dewey, 1938, 1974; Griffin, Holford, Jarvis, 2003). The individuals take part in situation which are chosen by themselves or suggested by the educator. Situations can be formal, informal; they are directly experienced and felt.

Experiential learning can be related to behaviour, activity, cognition or social relations, these forms can coexist because the experience itself has many dimensions (Griffin, Holford, Jarvis, 2003, see, e.g., Schön, 1987).

Bitinas considers the activity as the best educator comparing with verbal information, perception of sample image and communication because in activity, change of the student's motives does not take place upon the educator's suggestion or the student's wish; it is inherent to the activity itself. The new motive which is socially or individually more significant, relates to the previous motive, at first they as if compete, but thereafter the more important motive begins to dominate, and the previous one ceases to be important. The individual himself as subject of autonomous activity chooses, experiences, discovers, evaluates, considers, finds social ideas, testing them in his individual experience. The activity ensures a role of valuable subject to the student in pedagogical relations; it encourages to develop skills of evaluation - understanding of one's own feelings, testing alternative opinions, studying consequences of various choices, making a free and easy choice, expressing one's opinion and being active in conformity with one's conviction (Gredler, 1997; Brockbank, Megil, 2004). It allows the student to live the uncertainties and doubts, to make material his own "frame" and theories, subordinating them to conscious critics and changes, increased need for studies of personal importance (Wood, 2001). Conviction of the activity subject is confronted by real facts (where the fact can be also subject's emotions within the activity and as a result of it), and it changes, or else its meaning changes. Content of the activity 
determined the content of the experienced values. Bitinas advises the educator to choose one or other type of activity in compliance with the actual interests, needs and possibilities of the student. Such offer does not decrease the independence and self-expression of the students. The educator's broader life experience and education allows the educator to offer to the students a wider range of activities than the students themselves could (Битинас, 1984).

Crucial stage of development of values is evaluation. Within the study process, it should be included as the student's reflection of his own activity and experience.

The notion "reflection" has two meanings, likewise has the evaluation of the value experience: process when the experience is recognised, and the process, when new meanings and conceptions are formed from this experience. The reflection is a return to one's experience, first, by turning attention to one's emotional experience, second, by re-evaluating the experience (Moore, 2000).

Promptly after the activity, the student remembers his experience and describes it verbally (Schön, 1987). The process of evaluation is effective as far as the person is ready to open to his experience, observe oneself carefully and make sure that he well perceives his activity. Upon evaluating one's experience, it is important to be sensitive and authentic, in order to distinguish between one's opinion and previous social conceptions. Focus of evaluation is in the person himself, not outside. A grown-up person, when evaluating his experience, knows that the evaluation is flowing and changing, that the value may change, that the moment of experience is not only the impulse of the present moment, its meaning grows from similar experiences in the past, as well as from studying the possible consequences in future (Rogers, 1961). By individual reflection, the student records his emotions and thinks of the subjective meaning of the newly acquired experience (Леонтъев Д., 1998).

Schön expects that much of what was experienced during the activity is difficult to be verbally expressed but the aim of reflection is to notice what was not noticed before, and in a written form to name phenomena which were not verbally expressed before; this makes the subject of the activity to articulate what is actually done and what has happened during the process of activity. Ability to verbally express the meaning of the activity is the one which the educator has on a higher level than the student, and in this aspect, the educator's possibility is revealed to promote the student's learning from his experience (Schön, 1987). Help by the educator at reflection of the value content is offering the key words for direction of reflection.

Thus, the reflection should be verbal (best in writing), at first individual, afterwards dialogical. In dialogue with other students and the educator, the student discovers that there are possible alternative variants to the activity and that it is possible to choose such field of joint activities which is suitable for him. Individual reflection alone does not help revealing and using all potential of the individual. Sharing the new opinion with other students, listening to other opinions, grounding one's own, thus acquiring a concept of the force of collective knowledge, which leave out the traditional authorities. Such discussions may be somewhat inconvenient because sometimes painful and contradictory themes are tackled; however, as acknowledged by Wood, it is worth it because the student feels the importance of his autonomous judgement (Wood, 2001). Communication as means of development of the values by discussing and analysing various situations help apprehend the values of society, and the fact that there are other value systems which are different from the individual's opinion (Kohlberg, cf. Crain, 1985; Špona, 2004). Values are implemented and reflected by the student's communication with the educator and by communicating in small groups, by role plays and analysis of situations.

For evaluation of values within the pedagogical process, a special communication between the student and the educator, as well as among the students is necessary. Rogers advises the 
educator for facilitation of such evaluation to form such relations where the individual is accepted as a unique being having the freedom to experience his own feelings without threat and fear. It is expressed as 1) the educator's readiness to accept any behaviour of his student without critics, 2) care for each individual student as a special individual with his own opinions and values and 3) emphatic understanding of the student's expressions without evaluating and discussing (Rogers, 1961). A significant precondition for these conditions is the educator's avoidance of narcissism, namely, the opinion that his values are better than any other values. If you wish that the person learns your values, value him as high as possible (Colbeck, 2000). Such communication embodies relation subject - formation of subject between the student and the educator. Likewise during the mutual communication among students, the educator follows whether all opinions are listened to with respect and in the atmosphere of psychological security.

The pedagogical process has a socially or individually significant objective result - product, solution to the problem or discovery - and a subjective result - the student's experience, knowledge and values have changes (relations 5-6, Figure 2). Development of values as result of subjective process can be evaluated only the student himself. This type of evaluation is characterised by Schön's "reflection on reflection" as the highest level of reflection; here the student evaluates his learning within the reflection process. A well-though reflection process directs the student into the level of meta-cognitive / critical dialogue (Brockbank, Megil, 2004). Main criteria for evaluation are not the distinction, nor the conformity with any requirements which have been determined before, nor the mistakes and imperfections, but these are the student's change, development (as to the value aspect, this would be the recognition of changes to one's opinions, attitudes and aims) and improvement - as openness to constant changes and readiness to change (Kokse, 2003).

Figure 2. Development of professional values of the to-be teachers within the pedagogical process.

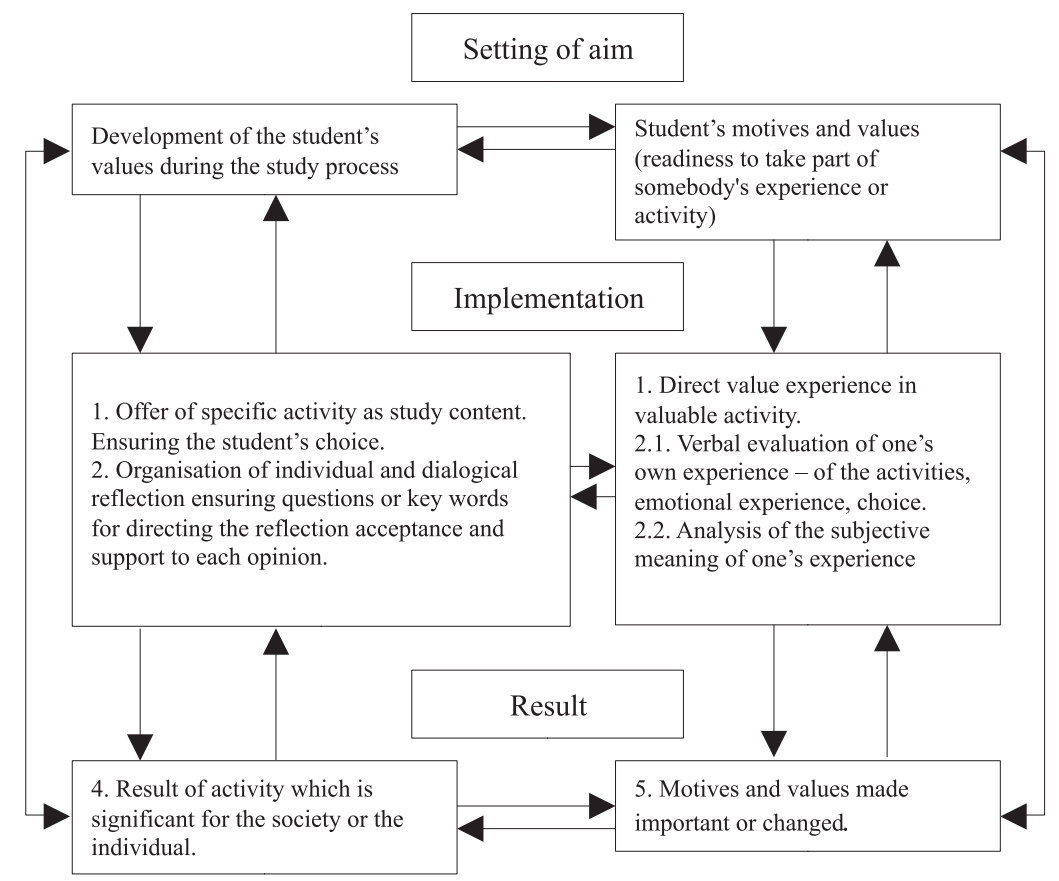


Observance of such conditions helps taking into account the student's needs, individual, social and cultural differences. The student becomes more independent, he is aware that this own autonomous opinion is unique but at the same time also "correct" just because it is his own formed by this own life experience. Time and space is acquired for experience significant for the student, respectively, for his life (Barnett, 2005). At the time of formal studies, the informal learning takes place; it goes together with the idea of "hidden" education program which is found as a significant part of education within the constructivistic education system (Tillla, 2005). Within the study process, the students have a possibility to formulate their opinions and to play arguments against them, develop criteria for evaluation of contradictory opinions. They have the opportunity to choose and enjoy the social consequences of their choice (Wood, 2001), to acquire experience of social contacts, expressing critical attitude towards values (Koķe, 2003). The educator has it as the possibility to ensure experience for the students, as he wishes to ensure. Each student group can be as a democracy laboratory where people get positive co-existing experience and skills of human relations (Knowles, 1990; Wood, 2001).

\section{Conclusions}

Development of subject's values takes place by experiencing definite values in direct experience and reflecting his experience in a special way. The more autonomous and mature is the personality, the less important is the external judgement, the larger is the evaluation of his personal experience and its meaning.

The student's value system develops spontaneously irrespective of whether the educator takes care of it or not. Within the pedagogical process, it is possible to improve the student's value system on purpose, creating circumstances for emotional experience of the values, for evaluation of their subjective and objective significance and regular practice. Within the study process, the educator includes activity and reflection as the study content.

Development of values does not take place by direct will of the subject; it does not have an intentional motivation. The activity developing the subject's motives has a different aim. Change of values or motivation is indirect result of activity, experience and its reflection. The only motivation which directs the person to the transformation of value system is personally significant motivation to get involved in some activity or experience. Within the pedagogical process, this is stimulated by significant, non-trivial issues related to the society or the student's personal life, which leaves space to the student's choice.

At institutions of higher education, the education programs do not develop values by giving place and time for acquisition of experience which would be personally important for the student, by creating circumstances where the student would take part in meaningful holistic activity, gain direct significant experience of values, adopt autonomous decisions, make choices, reflect his own experience and discuss it. Such cycle of pedagogical activity may be included in one lecture or course of studies; as well as in larger units of study process. The education content of the student's values is determined by the content of values experienced during the student's personally significant experience. Evaluation - related to self-evaluation.

Development of values within the study process needs a safe study environment where each student is highly appreciated as individual and listened to with respect. 


\section{REFERENCES}

1. Barnett R. (1994) The Limits of Competence. Buchingam, Philadelphia: SRHE \& Open University Press, 207 p.

2. Barnett R. (2003) Beyond all Reason: Living with Ideology in the University. Open University Press, 220 p.

3. Barnett R. (2005) Engaging the Curriculum in Higher Education. Maidenhead: Open University Press, $190 \mathrm{p}$.

4. Brockbank A., Megil J. (2004) The Action Learning Handbook, Rouledge 288 p.

5. Colbeck J. (2000) From Cultural Patchwork to Rainbows: Tightropes in Values Education. Moral Education and Pluralism. Ed. by Mal Leicester, Celia Modgil, Sohan Modgil, London: Falmer Press, p. 47-57.

6. Crain W. C. (1985) Kohlberg's Stages of Moral Development. Theories of Development. PrenticeHall. p. 118-136.

7. Dewey J. (1974) Experience and Education. New York: Collier Macmillan, 91 p.

8. Eisner, E. W. (1985) The art of educational evaluation. The Falmer Press, London\&Philadelphia, $195 \mathrm{p}$.

9. Eisner E. (2001) Explicit, Implicit and Null Curricula. Teaching In Mind: How Teacher Thinking Shapes Education. www.teachersmind.com/eisner.htm. (20.12.2007)

10. Encyclopedia of Higher Education (1992) Oxford, New York, Seul, Tokio: Pergaman Press.

11. Eriksons E. (1998) Jaunība. Identitāte un krīze. Rīga: Jumava, 271 lpp.

12. Gredler M. E. (1997) Learning and Instruction: Theory into Practice (3rd ed.). Upper Saddle River, New Jork: Prentice-Hall.

13. Griffin C., Holford J., Jarvis P. (2003) The Theory \& Practice of Learning. London: Kogan Page. $160 \mathrm{p}$.

14. Karpova Ā. (1994) Personība un individuālais stils. Rīga: Latvijas Universitāte, 291 lpp.

15. Knowles Malcolm S. (1950) Informal Adult Education. Chicago: Association press, 102 p.

16. Knowles Malcolm S. (1998) The Adult Learner. Houston, Texas: Gulf Publishing Company, 378 p.

17. Koķe T. (2003) Nepārtraukta izglītība: galvenie uzdevumi un to īstenošana. Nepārtrauktas izglītības sociāli pedagoǵiskie aspekti, Rīga: Izglītības soḷi, 4.-17. lpp.

18. Kron F. W. (1999) Grundwissen Didaktik, 3. erweiterte Auflage. München, Basel: Ernst Reinhard Verlag.

19. Medina Rivilla A. (2003) Didactica General. Prentice Hall, Madrid, 435 p.

20. Medina Rivilla A. (2005) Desarrollo de competencias profesionales mediante diseno de materiales y sistema tutorial. UNED www.enlaces.udec.cl/centrozonalsur/descarges/presentacion_medicarivilla. ppt 20. 12.2007

21. Moore A. (2000) Teaching and Learning: Pedagogy, Curriculum, and Culture. London: Routledge, $192 \mathrm{p}$.

22. Plaude I. (1999) Wertorientierungen der Jugendlichen im internationalen Vergleich. Hamburg: Verlag Dr. Kovač, $347 \mathrm{~S}$.

23. Rogers C. C. (1961) On Becoming Person. Boston: Houghton Mifflin Company, 420 p.

24. Rogers C. C. (1967) Modern Approach to Values: Maturity. New York: The Macmillan company, p. $40-54$.

25. Rokeach M. (1960) The Open and Closed Mind: Investigations into the Nature of Belief Systems and Personality Systems. Basic Books. New York. p. 392. 
26. Rokeach M. (1973) The Nature of Human Values. New York: Free press, 438 p.

27. Rubene Z. (2004) Kritiskā domāšana studiju procesā. Rīga: LU Akadēmiskais apgāds, 247 lpp.

28. Schön D. (1987) Educating the Reflective Practitioner, London: Jossey-Bass, 345 p.

29. Seligman C., Katz A. N. (1996) The Dinamics of Values Systems. The Psychology of Values, ed. by Mark Z., New York: Erlbaum L. Associates, Mahwah, p. 53-75.

30. Špona A., Čehlova Z. (2004) Pētniecība pedagogijāa. Rīga: Raka, 202 lpp.

31. Špona A. (2004) Audzināšanas process teorijā un praksē. Rīga: Raka, 190 lpp.

32. Schwarz S. H. (2006) Basic Human Values: Theory, Methods, and Applications. The Hebrew University of Jerusalem. http://www.fmag.unict.it/Allegati/convegno\%207-8-10-05/Schwartzpaper. pdf $(20.12 .2007$.

33. Tilı̣a I. (2005) Sociālkultūras mācī̌sanās organizācijas sistēma. Rīga: Raka, 295 lpp.

34. Walklin L. (2002) Teaching and Learning in Further and Adult Education. Nelson Thornes ltd. $194 \mathrm{p}$.

35. Vidnere M. (1997) Ar asarām tas nav pierādāms Rīga: LU, 313 lpp.

36. Wood D. (2001) Teacher as Citizen: Professional Development and Democratic Responsibility Transforming Teacher Education: Lessons in Professional Development. Ed. by E. K. Demulder, P. C. Lepage, H. T. Sockett, D. R. Wood. Westport: Bergin and Garvey, 257 p.

37. Битинас Б. (1984) Структура процесса воспитания. Каунас: Швиеса, 188 с.

38. Леонтъев А. Н. (1975) Деятельность. Сознание. Личность. Москва, Издательство политической литературы, $303 \mathrm{c}$.

39. Леонтъев Д. (1998) Введение в психологию искусства. Москва: Московский университет, $110 \mathrm{c}$.

40. Маслоу А. (2003) Мотивациия и личнось. Санкт-Петербург: Питер, 351 с.

41. Оллпорт г. (2002) Становление личности. Москва: Смысл, 462 с.

42. Столович Л. (1999) Философия. Эстетика. Смех. Санкт-Петербург: Тарту. 383 с.

43. Франкл В. (1990) Человек в поисках смысла. Прогресс, Москва. 368 с.

Lecturer Mg. art Ilze Briška

Riga Teacher Training and Educational Management Academy

Address: Šampētera iela 125 - 6, Riga, LV-1046, Latvia

Phone: +371 29247066

Fax: +37167808034

E-mail: $\underline{\text { ilze.briska@rpiva.lv }}$ 